\title{
To what Extent Do School Leaders in Slovenia Understand Physical School Environments as a Learning Factor?
}

Majda CENCiČ ${ }^{1}$

$\approx$ School leaders are a central factor of the quality of learning and teaching in schools. It is generally believed that the staff model their behaviour on leaders, which means if school leaders understand the physical school environment to be an important factor of learning, school staff (teachers and other professional staff) will also do so. To discover how school leaders assess the school environment as a factor of learning, 150 school leaders in primary education in Slovenia were invited to complete an online questionnaire. They were asked about their views regarding to what extent their school as physical environment encouraged certain factors. Fourteen listed factors were assessed on five-point numeric scales. The results show that in their school environment, school leaders assessed ecology, movement, and respect the highest, and feelings, imagination, and space the lowest. Their estimates of the assessed factors differ depending on the type of school building (new, old, renovated) only on the factors of movement, creativity, and logic and mathematics in favour of old schools. The results provide interesting information especially for school policy and everyone involved in the planning, building, or renewal of school premises.

Keywords: leadership, basic education, schools, physical environment, learning, Slovenia

1 University of Primorska, Faculty of Education, Slovenia; majda.cencic@pef.upr.si. 


\title{
Kako ravnatelji_ce zaznavajo fizični učni prostor kot dejavnik pouka?
}

\author{
MAJDA CENCIČ
}

$\propto$ Ravnatelji_ce imajo velik vpliv na kakovost učenja in poučevanja na svojih šolah. Splošno razširjeno je tudi mnenje, da delujejo kot model ali vzor za zaposlene in učenke_ce. Če npr. vodstvo ocenjuje fizično ali grajeno učno okolje kot pomemben dejavnik učenja, bodo učitelji_ce in učenke_ci tudi sprejele_i tak pogled na fizično učno okolje. Da bi ugotovili, kako ravnatelji_ce ocenjujejo notranje in zunanje okolje svoje šole, smo ravnatelje_ice slovenskih osnovnih šol povabile_i k sodelovanju in izpolnitvi spletnega vprašalnika. Zanimalo nas je, kako ocenjujejo fizično ali grajeno notranje in zunanje okolje svoje šole kot spodbujevalca nekaterih dejavnikov, ki smo jih oblikovale_i na osnovi Gardnerjeve teorije o več inteligencah. Na spletni vprašalnik se je odzvalo le 150 ravnateljev_ic osnovnih šol (od tega je bilo več kot 70 \% ravnateljic), ti_e pa niso vedno odgovorili_e na vsa vprašanja. Ravnatelji_ce so dejavnike ocenjevali_e na petstopenjski številčni ocenjevalni lestvici z ocenami od 1 (najnižja ocena) do 5 (najvišja ocena). Rezultati so pokazali, da so ravnatelji_ce ocenili_e, da notranje in zunanje okolje šole najbolj spodbujata ekologijo, gibanje in spoštovanje, malo pa čustva, domišljijo in prostor. $\mathrm{Na}$ osnovi tujih raziskav smo pričakovale_i, da bodo bolje ocenjene nove in obnovljene šole. Rezultati neparametričnega KruskalWalisovega preizkusa pa so pokazali statistično značilne razlike glede na vrsto šole (nova, stara, obnovljena) le pri dejavnikih gibanje, ustvarjalnost in logičnost ter matematika. V prednosti so se pokazale starejše šole, čeprav je bilo v Sloveniji zgrajenih veliko inovativnih in arhitekturno dobrih šol. Izpostavljamo le arhitekta Emila Navinška, ki je v sedemdesetih letih prejšnjega stoletja $\mathrm{z}$ inovacijo šol brez hodnikov spodbudil zanimanje arhitektov po vsem svetu za »brezkoridorne« stavbe.

Rezultati, ki smo jih dobile_i in jih zaradi nereprezentativnega vzorca ravnateljev_ic ne moremo posploševati, saj se je odzvalo le malo ravnateljev_ic iz novih šol, zato dajejo le neko grobo sliko pogleda ravnateljev_ic na nekatere dejavnike, ki jih spodbujata notranje in zunanje okolje šole, saj nas tudi okolje uči oz. tudi iz notranjega in zunanjega okolja sprejemamo številna sporočila. Rezultati pa tudi kažejo, da 
je treba področje grajenega šolskega prostora naprej raziskovati tudi na osnovi neposrednega opazovanja na terenu ter $\mathrm{v}$ raziskovanje vključiti različne deležnike_ce, ne le ravnateljev_ic, ampak tudi učitelje_ice, učenke_ce, starše in predstavnice_ke lokalne skupnosti.

Ključne besede: ravnatelji, osnovne šole, fizično učno okolje, učenje, Slovenija 


\section{Introduction}

School leaders have demanding and responsible roles, tasks, and responsibilities. They act as models, both for the staff and the students (Cencič \& Štemberger, 2014). If, for example, school heads understand the school environment to be an important factor in learning and teaching, the staff will also accept this view, because school space is not just space adapted for teaching (Ivanuš Grmek, 2003), but also a factor of learning, as it conveys many non-verbal messages (Day \& Midbjer, 2007).

It is not only the natural environment (e.g. forests, seaside) that exerts great influence on us, the built environment (e.g. internal and external school environments) also have significant influence, whether we are aware of this or not (Playce, 2012). Thus, the impact of the built environment on school climate, on health and on learning performance (Woolner, 2010) has been determined in the literature, which suggests that the school building acts as a third teacher (Nicholson, 2005), and educates (Ivanič, 2009), that schools themselves (building, playgrounds, rooms, and corridors) teach; they are passive lessons or silent lessons (Day \& Midbjer, 2007), hidden curriculum (Bida, 2012; Bregar Golobič, 2012; Taylor, 2009), and they can serve as three-dimensional textbooks for learning (Taylor, 2009). The school environment is becoming an additional factor of learning, as pupils accept the symbolic messages communicated by the school building and its surroundings.

Given that school heads function as models, we were interested in knowing how school heads in Slovenia assess their school environment as a factor of teaching and learning, which factors they rank the highest, and which lower, and whether the school heads' assessments differ depending on how old their school is. We created the factors based on Taylor's (2009, p. 153) presentation of how school environments can support Gardner's theory of multiple intelligences.

\section{Different roles and/or competences of school leaders}

School heads assume different roles in school today: '[P] rincipals are not only the educational leaders of their schools but managers who are responsible for financing, personnel, and the results of their institutions.' (Alava, Halttunen \& Risku, 2012, p. 16).

In Slovenia school heads' roles, tasks, and responsibilities are defined by law. It is emphasised among their roles that the school head is the person who takes care of the legality of school's functioning, taking account of school governing board's guidance and decisions, and that she/he is the coordinator of the work in the school (Roncelli Vaupot, 2001). 
In addition to the formally declared and defined roles, however, school heads also perform a number of various other roles they are expected to perform, despite the fact that they are not explicitly listed. ${ }^{2}$ Among such roles, ${ }^{3}$ we would like to mention that of a role model for teachers, because leaders act as a model for the staff, and that the staff tend to uncritically follow the example of school leaders. If the school head is also a model or example for the employees, for a good school head this represents an additional obligation.

In current discourse, the term 'school head's role(s)' has been increasingly replaced by the term school head's competences (e.g. Schratz et al., 2013). With reference to school head's competences, various more or less extensive lists of competences have been constructed (e.g. Schratz et al., 2013), which include various areas of knowledge, skills and attitudes. At present, however, the existing lists of competences do not include one that would indicate school head's competences in relation to the physical learning environment as an important factor of learning, although, as Tomšič Čerkez and Zupančič state: 'Physical space plays an important role in our everyday life. It determines us, and at the same time we define it' (2001, p. 5).

\section{Physical or built school environment as an additional learning factor}

According to Sigurđardóttir and Hjartarson (2011, p. 28):

Educational facilities and their surroundings can be a useful resource for teaching and learning in many ways. The shape of a building, lighting and facilities can serve as a subject for students in their studies. By making the building itself environmentally friendly, students can be taught to understand an environmentally friendly lifestyle. Architects might also consider opportunities to introduce interesting aspects of core subjects like maths, science and arts for teachers and students to reflect upon in different contexts. Patterns and lighting on the floor and ceiling might, for example, represent stars and galaxies, which then become a part of everyday life, and elements like doors, windows, light and shadows can be used to demonstrate colours, shapes, sizes and patterns.

2 In a qualitative study on creativity in pre-school institutions, the teachers highlighted the leadership, which in certain cases acts as a positive impulse for the creativity of the staff, or an impediment to it in other cases (Štemberger, 2013).

3 We understand the term 'role' to be the part someone assumes in any part of interaction (Richards \& Lockhart, 2007). Roles are not determined in advance, but change in relation to the changes in society and are culturally conditioned (ibid.). 
Anne Taylor (2009) presents similar opinions. She thinks that the school environment must be tailored to the individual learner and that this requires an awareness of the existence of different learning styles. Moreover, the school environment can also stimulate the expression of pupils' various intelligences, but only if it is varied and enables pupils to take part in different activities, such reading, listening to music, solving problems, etc. She explains pupils' potential and possibilities with Gardner's theory of multiple intelligences, which discusses the existence of several equal and relatively independent intelligences (verbal/ linguistic, logical/mathematical, visual/spatial, bodily/kinaesthetic, musical/ rhythmic, interpersonal, intrapersonal and naturalistic).

Taylor (ibid., p. 153) also presents a few ways that environments can support the identified intelligences, for example:

- verbal/linguistic: with a theatre in every school, multimedia communication centres;

- $\quad$ logical/mathematical: patterns built into the floor or walls, structural features revealed, places for technology, geometric form;

- $\quad$ visual/spatial: through a variety of spaces, sculptures, and wall graphics; galleries in schools, hallway museums; windows and interior views;

- bodily/kinaesthetic: with fitness trails, gymnasiums, dance studios, tools to use;

- musical/rhythmic: with acoustics, music practice rooms, performance venues;

- $\quad$ interpersonal: deployable and movable furniture, places for teamwork, large horizontal work surfaces versus individual desks, gathering spaces indoors and outdoors, conference rooms;

- $\quad$ intrapersonal: outdoor seating, study alcoves, private areas, quiet rooms;

- $\quad$ naturalistic: with habitats, recycling venues, nature trails, green architecture, etc.

Some researchers (e.g. Woolner, 2010) mention the influence of the environment not only on learning but also on the motivation of teachers and pupils. They discuss the influence of the environment on pupils' nonattendance at school, on their academic achievements, on bad discipline in worn out and inappropriately maintained school premises and argue that 'how one feels in school premises influences his/her relation to everything connected with education' (ibid., p. 15). These findings were supported by an analysis of the negative influence that neglected school premises have on pupils' behaviour and achievements (Burke \& Grosvenor, 2003). Taylor (2009) adds that ergodynamic furniture reduces the negative consequences of a sedentary lifestyle, which can include damaged posture, 
back pain, and even concentration problems. After comparing old schools with little natural light, poor views, built from inappropriate materials and with bad air circulation, etc. with newer, ecological schools with lots of daylight, good natural air circulation, a relaxing view etc., the researchers determined that learning achievements of pupils in newer, ecological schools were higher compared to the achievements of those pupils who attend schools with older and out-dated premises (LPA, 2009, p. 8). According to them, an appropriate learning environment also has a positive influence on work organisation, relations in the classroom, and motivation (Barret \& Zhang, 2009). The research results have proven the considerable importance and influence of the physical school environment.

The physical school environment functions as a learning factor or learning tool (Sigurđardóttir \& Hjartarson, 2011, p. 28) or 'passive lessons' taught every day (Day \& Midbjer, 2007). They (ibid., p. 147) add that lessons are absorbed from all places. Some are deliberate: for example, labelled cluster-bins encourage waste separation; some are unconsidered: for example overflowing litter bins encourage littering. The aforementioned authors argue that less conscious lessons include those about values, self-worth, behaviour, expectations, and responsibilities. All buildings and all places teach, but few have been planned with lessons in mind, because some devalue and demoralise us, while some enrich and inspire us (ibid.). Furthermore, Nicholson (2005, p. 44) presents evidence that children and pupils are extremely aware of the symbolic messages that buildings transmit. Therefore, she sees the building, the landscape of the school, the space and places within, the décor, furnishing and features as 'the third teacher': a tripartite alliance between teachers, parents and the environment in which the building takes place. She (ibid.) thinks that the very fabric of the school building can teach children and pupils about many things that will be important ideas they can grasp and hold onto throughout their lives.

Similarly, Pit Li Phan (in: OECD Programme on Educational Building and Department for Education and Skills, 2006, p. 44) explained: 'The shape, size and pattern of windows can demonstrate music, the pattern of light fittings can illustrate star constellations, and staircases can act as a sundial or a play structure.'

With regard to the mentioned influence, which the physical interior and exterior school environment exert on everyone participating in the learning process, we were interested to discover in what ways school heads perceive the physical environment (interior and exterior) of their schools as a factor of learning. We prepared the questionnaire according to Gardner's theory of multiple intelligences, which Taylor (2009) adapted to the physical or built school environment. With a questionnaire for school heads we also wished to stimulate their reflection and sensibility for the theme (Horvat, 2013), because we agree that data, 
like a mirror, give school leadership feedback about their schools (Conzemius \& O’Neill, 2001, p. 41).

\section{Survey}

The study took place in 2013. Only those parts of the results referring to the discussed theme are presented in the article. We were interested in how the surveyed school heads assess some of the factors in the environment of their schools and in what ways their estimates differ depending on how old the school building is (new building: less than five years; old building: more than five years; or renovated school). We expected that new and renovated schools would be assessed the best, according to the abovementioned LPA (2009) study in which the researchers found that learning achievements of pupils in newer, environmentally friendly school buildings were higher compared to the achievements of pupils who attend schools with older and outdated premises.

\section{Questionnaire}

In May 2013, heads of primary schools in Slovenia received an e-mail with the request to complete the questionnaire.

The questionnaire included a numerical rating scale, with which the school heads were asked to assess to what extent in their view their school as a physical environment encouraged certain factors (imagination, creativity, feelings, language, music, logic and mathematics, space, movement, ecology, aesthetics, cooperation among students, respect, ethics and attitude towards the broader community). The influence was assessed on a five-point scale: 1 (weak influence) to 5 (strong influence).

\section{Sample}

After repeating the invitation to participate three times, 150 school heads 4 responded to the request; 40 male $(26.7 \%)$ and 109 female $(72.7 \%)$ school heads completed the questionnaire; one of the respondents did not indicate gender.

As for the education level, one respondent had concluded a higher vocational study programme, 20 (13.3\%) a higher education professional study programme, $99(66.0 \%)$ a university study programme, one had a Bologna master's degree, and $29(19.3 \%)$ have concluded a specialisation, master of science or doctor of science degree.

4 The questionnaire was dispatched to 787 addresses of school heads in primary education. 
The age of 91 (60.7\%), of the school heads who responded to the questionnaire was between 51 and 60 years; $51(34.0 \%)$ were in the age range between 41 and 50 years, 6 (4.0\%) between 31 and 40 ; only two (1.3\%) of the school heads who responded to the internet questionnaire were older than 61 years .

One respondent did not select an answer to the question about job experience in leadership; 38 respondents $(25.3 \%)$ had up to four years of professional experience in school leadership; $73(48.7 \%)$ had been in leadership for 5 to 14 years, and 38 (25.3\%) for more than 15 years.

Most numerous (66 or $44 \%$ ) among the respondents were school heads of rural schools, followed by $56(37.3 \%)$ heads of urban and $28(18.7 \%)$ heads of suburban schools.

As stated in the responses, only three $(2.0 \%)$ of the school heads worked in new (up to 5 years old) school buildings. Most of them, i.e. 92 or $61.3 \%$ school heads worked in school buildings more than five years old; the rest of the surveyed school heads ( 55 or $37.7 \%$ ) worked in renovated schools.

\section{Data processing}

The data were processed at the level of descriptive and inferential statistics. The school leaders' answers were first ranked according to their calculated mean values, from the factors with the highest mean value to the factors that on average were graded as less important. Descriptive statistics of the responses include the minimum result, the maximum result, the mean, the standard deviation, the coefficient of skewness and the coefficient of kurtosis. Nonparametric statistics: Spearman's rho correlations were used for connections between factors, and the Kruskal-Wallis test for the comparison of school heads' assessments with regard to the type of their school (new, renovated, or old). ${ }^{5}$

5 The Kruskall-Wallis test was applied because of the non-normal distribution of assessed factors and because of the small number of school heads in new (less than five years old) schools. 


\section{Results and interpretations}

Table 1: Descriptive statistics of graded factors that are, according to school leaders in basic education, stimulated by the physical school environment.

\begin{tabular}{lccccccc}
\hline Factors & $\mathbf{N}$ & Min & Max & Mean & Std. Deviation & Skewness & Kurtosis \\
\hline Ecology & 147 & 2 & 5 & 4.13 & .870 & -.824 & .053 \\
Movement & 146 & 1 & 5 & 4.09 & .813 & -.712 & .555 \\
Respect & 146 & 1 & 5 & 4.03 & .805 & -.614 & .479 \\
Cooperation among pupils & 147 & 2 & 5 & 4.02 & .716 & -.257 & -.356 \\
Language & 148 & 1 & 5 & 3.99 & .782 & -.754 & 1.536 \\
Ethics & 148 & 1 & 5 & 3.97 & .833 & -.738 & .992 \\
Attitude towards broader & 148 & 1 & 5 & 3.96 & .848 & -.736 & .859 \\
community & 148 & 2 & 5 & 3.87 & .767 & -.143 & -.536 \\
Music & 148 & 2 & 5 & 3.86 & .822 & -.340 & -.387 \\
Creativity & 147 & 1 & 5 & 3.85 & .753 & -.430 & .652 \\
Logic and mathematics & 148 & 2 & 5 & 3.64 & .881 & -.199 & -.629 \\
Aesthetics & 149 & 1 & 5 & 3.48 & .768 & .012 & .145 \\
Feelings & 149 & 1 & 5 & 3.44 & .791 & -.119 & -.030 \\
Imagination & 145 & 2 & 5 & 3.43 & .814 & .081 & -.465 \\
Space & & & & & & & \\
\hline
\end{tabular}

The participating school heads assessed all the factors as relevant, as the average of all ratings exceeds 3 on the five-point assessment scale. With the average exceeding 4 , distribution asymmetrically skewed to the left, prevalence of ratings 4 (40.7\% of all ratings) and 5 (38.0\% of all school heads' ratings) they rated ecology the highest in their schools. No one rated ecology in her/his school 1, which indicates the school heads estimate the factor of ecology highly and also dedicate the largest amount of attention in the environment to this theme (e.g. waste sorting).

Furthermore, the factor movement reached a high average rating (above 4) with rating 4 or strong influence also prevailing in this case $44.0 \%$ of all school heads' ratings). Schools with gym(s), sport grounds, and play facilities develop the factor movement very intensively. Navodila za graditev osnovnih šol v Republiki Sloveniji (Instructions for the Construction of Primary Schools in the Republic of Slovenia (2007) explicitly state that the school ground also includes the school yard, with or without playing facilities, and sport grounds. They list indoor training facilities (e.g. dance workshop, table-tennis room, sports games halls, swimming pool, fitness room) and outdoor sport grounds for basic school 
(e.g. platform for sports games, a four-lane running track, a shot-put facility, a runway for the long jump, etc.).

Considering the results, school heads are mainly satisfied with the facilities in their schools intended for movement, as only one school head selecting the rating 1 here, which indicates the school does not have suitable and adequate facilities (such as aym), which would motivate the students to movement, at its disposal.

We also obtained rather unexpectedly high ratings regarding the factor respect (average exceeding 4 with nearly half (46.0\%) of the school heads rating this factor at 4). Ciaccio (2004) stresses the importance of respect in schools; he (ibid., p. 3-4) thinks that respect fulfils the child's emotional need and that treating pupils with respect is a practice that most educators would embrace. Meador (2013) states respect denotes both positive feelings of esteem for a person and also specific actions and conduct representative of such esteem. He adds that respect can be defined as allowing oneself and others to do and be their best. According to Meador (ibid.), it is important to create a mutually respectful atmosphere between all individuals involved within a school; all entities are expected to remain respectful to each other at all time and to greet each other with kind words. I believe it is the wish, ambition and, endeavour of every school head the their school would demonstrate respect to all and everyone. In schools, respect is also shown through the esteem of each student's characteristics including the adaptations necessary for children with special needs, such as ramps, adapted toilet rooms, etc.

Cooperation among pupils also achieved an average slightly exceeding a rating of 4 , with that rating having the largest (52.0\%) share of ratings. Taylor (2009) argues that the school environment with its surroundings can stimulate cooperation among pupils with outdoor seating, study alcoves, private areas, quiet room, with deployable and movable furniture, places for teamwork, large horizontal work surfaces versus individual desks, gathering spaces indoors and out, conference rooms, etc. School heads promote cooperation among pupils very much and probably they also place such furniture and equipment in their schools that support cooperation among students.

As previously noted, Taylor (2009) also thinks that the school environment with its surroundings can stimulate language with a theatre in every school or with multimedia communication centres. In the Navodila za graditev osnovnih šol v Republiki Sloveniji (Instructions for the Construction of Primary Schools in the Republic of Slovenia) (2007) a theatre is not explicitly mentioned. In the group 'functional rooms', a multipurpose room, with club spaces for students suitable for cultural events, lectures, art exhibitions, literary events, celebrations, etc. is mentioned among 'other rooms'. 
Furthermore, the corridors of Slovenian basic schools are usually decorated with various posters with visual and/or verbal messages, so more than half (51.3\%) of the school heads rated this factor in their schools at 4.

School heads are probably aware that the Slovenian language needs to be cultivated and paid particular attention, also because we are in the era of globalisation, when English as the lingua franca is gaining prevalence in Slovenia.

Ethics in society is a theme much discussed in Slovenian daily press and on TV; a lack or crisis of values are mentioned, especially emphasised in religious periodicals (e.g. Žajdela, 2013, p. 1). Similarly, it is also stated elsewhere that lack of ethics and ethical conduct has received a great deal of attention by the media (Humphrey, Janosik \& Creamer, 2004, p. 675), and also that ethics is part of every interaction (Lampkin \& Gibson, 1999, in: ibid., p. 677). Therefore, in the evaluation of their school environment, school heads were able to put much emphasis on this aspect of school: in this case, the rating of 4 was also prevalent (47.3\% of all).

The attitude towards the broader community received quite high ratings and the prevalence rating of 4 ( $46.7 \%$ of all respondents). We can assume the reason behind this is that emphasis on cooperation and partnership is often present in Slovenian educational literature, but also the school practice, because schools often work together with local communities in organising and performing various celebrations. In the afternoon and in the evening, they lend school facilities, especially gyms, to be used for the recreation of the local people.

Furthermore, music was awarded a high average and here, too, a rating of 4 prevailed ( $47.3 \%$ of the investigated school heads). Music is developed with acoustics, with music practice rooms, performance venues, etc. (Taylor, 2009, p. 153). Among specialised classrooms in Slovenian schools, there are also music rooms with various musical instruments, which school heads evaluated highly.

Creativity received a high average rating, and the rating 4 prevailed also in this factor (46.7\% rated creativity 4). Taylor (2009, p. 315) understands creativity very broadly, as an aspect of human behaviour that encompasses more than the creativity of an artist or a composer. According to her, creativity is also the way you form a word as you speak, to imagine an image in your mind, or to recognise the smell of a flower - everything that did not exist before. Creativity can also be promoted through flexible furniture, various corners, such as a puppet corner and similar, in primary schools.

Furthermore, the factor of logic and mathematics received a high average rating and the prevalence rating of 4 , which was selected by more than half (52.0\%) of school heads. Taylor (2009) thinks that the school environment with its surroundings can stimulate logic and mathematics with patterns built into the floor or walls, structural features revealed, places for technology, geometric 
forms, etc. Probably also school heads are aware of this factor, but I am not sure whether during the construction of premises they had considered including special patterns in the floors and on school walls. In Slovenian schools, however, a great number of various geometrical models and other mathematical learning aids are exhibited.

With regard to aesthetics, the ratings of 4 (strong influence), selected by $42.0 \%$ of school heads and 3 (medium), selected by $30.0 \%$ of school heads, prevailed. In the Navodila za graditev osnovnih šol v Republiki Sloveniji (Instructions for the Construction of Primary Schools in the Republic of Slovenia) (2007), a special classroom for arts is mentioned, which should preferably be located on the ground floor to allow performing activities outside the building. Aesthetics, of course, cannot be developed just through a special classroom for arts; the whole school must participate in this. As high ratings prevailed, the ratings given by the school heads that evaluated the aesthetics (interior and exterior) of their schools indicate they are quite satisfied. This is also shown in the appearance of schools and their surroundings, which usually are quite tidy and carefully maintained. Furthermore, Taylor (2009, p. 79), who combines education with architecture, wrote: 'Can't learn in ugly' She thinks children demonstrate an intuitive sense of beauty and an innate ability to read and respond to the environment. Woolner (2010) argues that poor school premises seem to be associated with poor outcomes and that, even though the relationship is not simple, there are likely to be benefits for improving an inadequate environment.

The factor of emotions was predominantly awarded a rating of 3 (medium) with $46.0 \%$ of the investigated school heads and a rating of 4 (strong influence) selected by $38.0 \%$ of respondents. Feelings are an integral part of life in schools, too. As Rudolf Steiner in 1919 said (in: Day \& Midbjer, 2007, p. 8), infants also absorb the quality of their environment, and older children respond to how places feel.

With regard to average ratings, the factor imagination is ranked below emotions. Here, too, a rating of 3 (medium) with $42.7 \%$ of school heads and a rating of 4 (strong) with $39.3 \%$ of school heads prevailed. Rodari (1996, p. 126) argues that imagination is based on real life materials and that it is important for children to live in an environment full of impulses and stimulation. According to Rodari (1996, p. 128), the main characteristics of learning premises should be their changeability and the possibility of giving its users enough opportunities not to accept it passively, but to actively and with creativity influence the space itself.

In comparison to other factors, space received the lowest average rating, although still above the average of 3 (medium influence) selected by $41.3 \%$ of the investigated school heads and with a rating of 4 ticked by $35.3 \%$ of them. By 'space', 
we mean architectural design, and it is one of the fields introduced to pupils as a part of art education (Tomšič Čerkez \& Zupančič, 2011, p. 8). Pupils experience space and relationship within it through their own movement, their senses and in a real environment (ibid.). Taylor (2009) thinks that the school environment with its surroundings can stimulate visual or spatial factors through a variety of spaces, sculptures, and wall graphics; galleries in schools, hallway museums; windows and interior views. Slovenian schools do not usually possess works of art by renowned artists; they exhibit their students' works instead. It might be useful both for the development of arts and of the students if also here the practice that has been established in Austria were active, where it is stipulated by law that every newly built school must earmark part of the investment for purchasing works of art (Kuhar, 2009). In this way, the students who do not have opportunities to encounter arts at home can compensate for this in school, where they spend much of their time.

As already mentioned, all the listed factors received high average ratings, which means school heads had ascribed all of them a strong influence and also evaluated them well as factors of learning in their schools. The listed factors also correlate to each other, for all the enumerated factors a positive and statistically significant correlation (Spearman's rho coefficient) ranging between $0.187(2 \mathrm{P}=0.023)$ for the relation between imagination and music, ${ }^{6}$ and 0.86 $(2 \mathrm{P}=0.000)$ for the relation between respect and ethics was present.

With regard to the social climate, which puts emphasis on the ecological aspect and the importance of movement, it is not surprising that the two factors received the highest average ratings. More unexpected are the high ratings for respect in school, which we accept as positive, and the high correlation coefficients for respect and cooperation among pupils (rho $=0.653,2 \mathrm{P}=0.000$ ) respect and ethics ( $\mathrm{rho}=0.786,2 \mathrm{P}=0.000$ ), which, as mentioned, is the highest, and respect and attitudes towards broader community ( $\mathrm{rho}=0.645,2 \mathrm{P}=0.000)$. Probably, this interpersonal factor should also receive more attention in the literature, although some authors emphasise (e.g. Ciaccio, 2004) respect. Close links between the listed factors are also mentioned by others, namely that e.g. only sound imagination can be the driving force behind the creation of something new as well as being important for learning as real knowledge only grows out of one's own creativity (Hanuš, in: Bizjak, 1996). A close link between imagination and creativity was also determined in our study ( $r h o=0.668,2 \mathrm{P}=0.000$ ).

Despite statements like: 'There can be no movement or activity on any scale where there is no room to move', (Woolner, 2010, p. 21) the ratings for space,

6 The results of Spearman's rho between music and imagination surprised us. Since it is stated all great achievement in the areas of music, arts, architecture, and science represent a leap in imagination (Beuermann, 2011, p. 33) we had expected a higher correlation coefficient. 
though still above the medium rating, were the lowest. Perhaps school heads had perceived a lack of space in their schools. If the factor of space is significant, it should be aesthetically pleasing ( $\mathrm{rho}=0.442,2 \mathrm{P}=0.000$ ), it should develop imagination $(\mathrm{rho}=0.358,2 \mathrm{P}=0.000)$, creativity $(\mathrm{rho}=0.342,2 \mathrm{P}=0.000)$, cooperation among students $(\mathrm{rho}=0.317,2 \mathrm{P}=0.000)$, and cooperation with the environment ( $\mathrm{rho}=0.268,2 \mathrm{P}=0.001$ ), as well as positive emotions ( $\mathrm{rho}=0.392,{ }_{2} \mathrm{P}=0.000$ ) and respect ( $\mathrm{rho}=0.247,2 \mathrm{P}=0.003$ ). Space should also be ecologically oriented ( $\mathrm{rho}=0.417,2 \mathrm{P}=0.000$ ) and should promote movement (rho=0.472, $2 \mathrm{P}=0.000$ ), as it is commonly known that students do not currently move enough.

We complement the described evaluation by school heads and the correlation of the presented factors with a comparison regarding the time of the construction of the school building: new, old, renovated (Table_2).

Table 2: Results of Kruskal-Wallis test for the listed factors in relation to the time of construction.

\begin{tabular}{|c|c|c|c|c|c|c|}
\hline \multirow{2}{*}{ Factors } & \multirow{2}{*}{ School } & \multirow{2}{*}{$\mathrm{N}$} & \multirow{2}{*}{ Mean Rank } & \multicolumn{3}{|c|}{ Kruskal Wallis Test } \\
\hline & & & & Chi-Square & df & Asymp. Sig. \\
\hline \multirow{4}{*}{ Ecology } & New & 3 & 79.67 & \multirow{4}{*}{2.989} & \multirow{4}{*}{2} & \multirow{4}{*}{.224} \\
\hline & Old & 90 & 78.26 & & & \\
\hline & Renovated & 54 & 66.58 & & & \\
\hline & Total & 147 & & & & \\
\hline \multirow{4}{*}{ Movement } & New & 3 & 49.00 & \multirow{4}{*}{8.074} & \multirow{4}{*}{2} & \multirow{4}{*}{.018} \\
\hline & Old & 89 & 80.73 & & & \\
\hline & Renovated & 54 & 62.94 & & & \\
\hline & Total & 146 & & & & \\
\hline \multirow{4}{*}{ Respect } & New & 3 & 69.00 & \multirow{4}{*}{1.607} & \multirow{4}{*}{2} & \multirow{4}{*}{.448} \\
\hline & Old & 89 & 76.79 & & & \\
\hline & Renovated & 54 & 68.32 & & & \\
\hline & Total & 146 & & & & \\
\hline \multirow{4}{*}{$\begin{array}{l}\text { Cooperation among } \\
\text { pupils }\end{array}$} & New & 3 & 71.50 & \multirow{4}{*}{1.936} & \multirow{4}{*}{2} & \multirow{4}{*}{.380} \\
\hline & Old & 90 & 77.52 & & & \\
\hline & Renovated & 54 & 68.28 & & & \\
\hline & Total & 147 & & & & \\
\hline \multirow{4}{*}{ Language } & New & 3 & 74.00 & \multirow{4}{*}{4.044} & \multirow{4}{*}{2} & \multirow{4}{*}{.132} \\
\hline & Old & 90 & 79.62 & & & \\
\hline & Renovated & 55 & 66.15 & & & \\
\hline & Total & 148 & & & & \\
\hline \multirow{4}{*}{ Ethics } & New & 3 & 73.00 & \multirow{4}{*}{.647} & \multirow{4}{*}{2} & \multirow{4}{*}{.724} \\
\hline & Old & 90 & 76.60 & & & \\
\hline & Renovated & 55 & 71.15 & & & \\
\hline & Total & 148 & & & & \\
\hline
\end{tabular}




\begin{tabular}{|c|c|c|c|c|c|c|}
\hline \multirow{2}{*}{ Factors } & \multirow{2}{*}{ School } & \multirow{2}{*}{$\mathrm{N}$} & \multirow{2}{*}{ Mean Rank } & \multicolumn{3}{|c|}{ Kruskal Wallis Test } \\
\hline & & & & Chi-Square & df & Asymp. Sig. \\
\hline \multirow{4}{*}{$\begin{array}{l}\text { Attitude towards } \\
\text { broader community }\end{array}$} & New & 3 & 91.83 & \multirow{4}{*}{.610} & \multirow{4}{*}{2} & \multirow{4}{*}{.737} \\
\hline & Old & 90 & 73.69 & & & \\
\hline & Renovated & 55 & 74.88 & & & \\
\hline & Total & 148 & & & & \\
\hline \multirow{4}{*}{ Music } & New & 3 & 80.17 & \multirow{4}{*}{4.031} & \multirow{4}{*}{2} & \multirow{4}{*}{.133} \\
\hline & Old & 90 & 79.52 & & & \\
\hline & Renovated & 55 & 65.98 & & & \\
\hline & Total & 148 & & & & \\
\hline \multirow{4}{*}{ Creativity } & New & 3 & 79.83 & \multirow{4}{*}{8.095} & \multirow{4}{*}{2} & \multirow{4}{*}{.017} \\
\hline & Old & 91 & 81.63 & & & \\
\hline & Renovated & 54 & 62.19 & & & \\
\hline & Total & 148 & & & & \\
\hline \multirow{4}{*}{$\begin{array}{l}\text { Logic and math- } \\
\text { ematics }\end{array}$} & New & 3 & 63.00 & \multirow{4}{*}{8.920} & \multirow{4}{*}{2} & \multirow{4}{*}{.012} \\
\hline & Old & 89 & 81.70 & & & \\
\hline & Renovated & 55 & 62.15 & & & \\
\hline & Total & 147 & & & & \\
\hline \multirow{4}{*}{ Aesthetics } & New & 3 & 107.50 & \multirow{4}{*}{2.097} & \multirow{4}{*}{2} & \multirow{4}{*}{.351} \\
\hline & Old & 90 & 74.44 & & & \\
\hline & Renovated & 55 & 72.80 & & & \\
\hline & Total & 148 & & & & \\
\hline \multirow{4}{*}{ Feelings } & New & 3 & 87.00 & \multirow{4}{*}{.288} & \multirow{4}{*}{2} & \multirow{4}{*}{.866} \\
\hline & Old & 91 & 74.54 & & & \\
\hline & Renovated & 55 & 75.11 & & & \\
\hline & Total & 149 & & & & \\
\hline & New & 3 & 88.50 & & & \\
\hline Imagination & Old & 91 & 74.49 & 357 & 2 & 876 \\
\hline IIIagmation & Renovated & 55 & 75.10 & 153 & 2 & .850 \\
\hline & Total & 149 & & & & \\
\hline & New & 2 & 106.00 & & & \\
\hline Snare & Old & 88 & 77.11 & 4548 & 2 & 107 \\
\hline space & Renovated & 55 & 65.23 & 4.548 & 2 & .103 \\
\hline & Total & 145 & & & & \\
\hline
\end{tabular}

Since the number of school heads in new schools and of primary schools, in general, participating in the survey was not sufficient, the results of the study can only serve for deliberation. As the results in Table 2 indicate, the differences in school heads' evaluations were statistically significant in just three of the factors listed: movement, creativity, and logic and mathematics. In all the three factors, the average ratings were higher for old schools (schools older than five years), which achieved the highest ratings.

'Old schools' also achieved the highest average ratings, although without statistically significant differences, also in the factors, movement, respect, cooperation among pupils, language, and ethics. 
In contrast, 'new schools' have the highest average of rankings, although without statistically significant differences in evaluations, with the factors ecology, attitude towards broader community, music, aesthetics, feelings, imagination, and space. With regard to the results that speak in favour of 'old schools', we can nevertheless ask a few questions about 'new schools'. In relation to our expectations, in our case, new schools did not receive ratings statistically higher than old and renovated schools, although in Slovenia there are the Navodila za graditev osnovnih šol v Republiki Sloveniji (Instructions for the Construction of Primary Schools in the Republic of Slovenia) (2007) and in literature there is much discussion about schools for the 21st century or about schools for the future (e.g. Dudek, 2005; LPA, 2009; PEB Exchange... 2002; Sigurđardóttir \& Hjartarson, 2011). Slovenian architects also underscore that since World War II a large number of schools have been built with well-considered spatial solutions, innovative construction concepts, new materials, colours, and lighting elements (Filipič et al., 2004, p. 26). We can highlight Navinšek's 'corridor-less schools' which 'became a term and a concept for designing schools' (Bregar Golobič, 2012, p. 76).

I would like to stress that we do not wish to generalise the results, because only the evaluations of a modest number of school heads of 'new schools' were available to us. They indicate, however, that this area needs to be analysed and studied further, also with the help of direct observation and evaluations from the field and to include different stakeholders: besides school heads, also teachers, other school staff, students, parents and the wider community (Woolner, 2010).

The results also indicate the designing of new and of renovating existing schools needs to be given special attention. All stakeholders need to be involved in the designing of new and renovation of old buildings. Kenkmann (2011) states that children could monitor, arrange, and be involved in the maintenance of the school. They could take the initiative on how to decorate the classroom or the school and put up displays that are important to them rather than having educational posters chosen by the teacher. He (ibid.) adds that changing the space around us does not necessarily involve high costs and that what is needed is only some creativity and democratic structure in the school. With the participation of students, school heads can also serve as a model to teachers for cooperation in and joint planning of the school facility as a factor of learning. They state pupils learn by observing and participating (Day \& Midbjer, 2007.) Therefore, school leaders must take care that the learners receive a variety of positive messages from the interior as well as from the exterior environments of their school. 


\section{Conclusion}

We have found that school heads perceive the physical school environment to be factors of learning in their schools. The school heads participating in the study attributed the strongest influence to ecology, movement, and respect. They also perceive other factors, such as cooperation among pupils, language, ethics, attitude towards the broader community, etc., as important in their physical school environment, as all the factors mentioned received average ratings above the mean rating of 3 on the five-point rating scale.

With reference to how old the school is (new, old, renovated) statistically significant differences were acquired only with the factors of movement, creativity, and logic and mathematics, where, in comparison with new and renovated school buildings, they scored the lowest. We were surprised by this result, because old buildings were given preference over new and renovated schools in the factors respect, cooperation among pupils, language, and ethics, although with no statistically significant differences. New schools only scored slightly higher than old and renovated buildings did in the factors of ecology, attitudes towards broader community, music, aesthetics, feelings, imagination, and space. We would like to stress again that only a very small number of school heads from new schools were included in the sample and that we cannot consequently generalise the results. We might have achieved different results if more school heads of new schools had participated. Therefore, this area should be researched further. However, the findings do convey important messages to architects and all others involved in shaping school policy and planning the building or renewal of school premises. As Vodopivec (2014) puts it, architecture is a collective work, deserving of several collaborators in the production of the plan, in building, furnishing, etc. and the work of an architect should be broadly 'socially' accepted to be able to appear at all and also to meet the client's desires. In our paper, we have focused only on the pedagogical aspect, from the perspectives of school heads.

Moreover, in planning, 'consensus design' (Day \& Parnell, 2003) is discussed, which is a socially inclusive process that includes different stakeholders. Only joint planning, implementation, and then evaluation of the creation can have positive effects on everyone, especially on users, as architects (e.g. Vodopivec, 2014) also believe some spaces have 'special power' or 'soul', which Day (2004) discusses in the book titled 'Places of the Soul'.

In addition to what has been stated so far, we wished, by filling in the questionnaire, school leaders would be encouraged to reflect on the nonverbal communication of their schools and to foster environmental and social awareness and responsibility (Day \& Midbjer, 2007) for the built environment of their 
school, which is an important learning factor. We suppose the questionnaire has stimulated school heads to think about what their schools look like, and that attention needs to be paid the school building (interior and exterior school environment) itself. As emphasised in literature (e.g. Day \& Parnell, 2003), all stakeholders (besides architects and builders, also school heads, teachers, other school staff, pupils, parents, and representatives of the local community), need to be involved in the designing of new or the renovation of old buildings.

This paper could also be informative for the architects who think that architecture matters (Day, 2004). To architects, we would like to convey not only the general negative message that many people complain about modern architecture (ibid.). Architects could become familiar with the perspective of school leaders, how they assess their school environment, because adults, and not only children, behave differently in different environments and feel, think, and act differently in different surroundings (ibid.). As Vodopivec (2014) also says, the process of designing and building even of a quite modest facility requires increasingly more diverse skills, which in our time an individual can no longer master.

\section{References}

Alava, J., Halttunen, L., \& Risku, M, (2012). Changing School Management: Status Review 13. Finnish National Board of Education. Retrieved from http://www.oph.fi/download/146781_Changing_ school_management.pdf.

Barett, P., \& Zhang, Y. (2009). Optimal Learning Spaces Design Implications for Primary Schools. SCRI Research Report/on line/. Retrieved from http://www.oecd.org/dataoecd/38/47/43834191.pdf. Beuermann, D. (2011). Celostna šola: Proces sedmih izzivov [Holistic School: The Process of Seventh Challenges]. Ljubljana: Debora.

Bida, G. (2012). Prikriti kurikulum, ideologija, prostor [Hidden Curriculum, Ideology and Space]. Sodobna pedagogika, 63(1), 96-111.

Bizjak, H. (1996). Sprostitev in ustvarjalnost v šoli: Pedagogika za tretje tisočletje [Relaxation and Creativity in School: Pedagogics for the third Millennium]. Ljubljana: samozaložba (self-published). Bregar Golobič, K. (2012). What Kind of School Do We Want? The Architecture of Schools as an Element of (Hidden) Curriculum. Sodobna pedagogika, 63(1), 74-94.

Burke, C. (2005). The Edible Landscape of School. In M. Dudek (Ed.), Children's spaces (pp. 245-277). New York: Routledge.

Cencič, M., \& Štemberger, T. (2014). Vodenje vzgojno-izobraževalnih zavodov in vpliv na ustvarjalnost vzgojiteljev [Leading Educational Institutions and its Impact on Teachers' Creativity]. Sodobna pedagogika, 65(4), 66-80. Ciaccio, J. (2004). Totally Positive Teaching: A Five-Stage Approach to Energizing Students and Teachers. Alexandria: Association for Supervision and Curriculum development. 
Conzemius, A., \& O’Neill, J. (2001). Building Shared Responsibility for Student Learning. Alexandria: Association for Supervision and Curriculum Development.

Day, C. (2004). Places of the Soul: Architecture and Environmental Design as a Healing Art. London, New York: Routledge Taylor and Francis Group.

Day, C., \& Midbjer, A. (2007). Environment and Children: Passive Lessons from the Everyday Environment. Amsterdam etc.: Elsevier Ltd.

Day, C., \& Parnell, R. (2003). Consenzus Design: Socially Inclusive Process. Oxford etc.: Architectural Press.

Dudek, M. (ed.) (2005). Children's Space. New York: Routledge.

Filipič, P., Kavčič, L., Kuhar, Š., Maljavac, T., Struna Bregar, A., \& Viki Šubic, B. (2014). Igriva arhitektura [Playing Architecture]. Ljubljana: Zavod Republike Slovenije za šolstvo.

Horvat, B. (2013). On lesson and reflective form of life: 13. medunarodni znanstveni skup 'Dani Mate Demarina'. Obrazovanje za razvoj, Pula, 11 and 12 April 2013.

Humphrey, E., Janosik, S. M., \& Creamer, D. G. (2004). The Role of Principles, Character, and Professional Values in Ethical Decision-Making. NASPA Journal, 41(3), 675-692. Retrieved from http://www.elps.vt.edu/janosik/StuDev2oog/EthicalDecisionMaking.pdf.

Ivanič, M. (2009). Šola vzgaja. Šola in trajnostni razvoj [Schools as Teachers. Sustainable School Buildings: From Concept to Reality]. In Mednarodna konferenca (International conference). Ljubljana, SLO, 1-2 October 2009). Retrieved from www.mss.gov.si/si/konferenca_oecd. Ivanuš Grmek, M. (2003). Učni prostor [Learning space]. In M. Blažič, M. Ivanuš Grmek, M. Kramar, \& F. Strmčnik (Eds.), Didaktika: Visokošolski učbenik [Didactics: Higher Education Textbook] (pp. 322-328). Novo mesto: Visokošolsko središče, Inštitut za raziskovalno in razvojno delo. Kenkmann, A. (2011). Adapting and Design in Spaces: Children and their Schools. CEPS Journal, $1(2), 11-24$.

Kuhar, Š. (2009). Šola vzgaja. Šola in trajnostni razvoj [Schools as Teachers. Sustainable school buildings: From concept to reality]. Mednarodna konferenca (International conference). Ljubljana, SLO, 1-2 October 2009. Retrieved from www.mss.gov.si/si/konferenca_oecd.

LPA (2009). Green School Primer: Lessons in Sustainability. Mulgrave: The Images Publishing Group. Meador, D. (2013). Respect in Schools: A Policy to Promote Respect in Schools. Retrieved from http://teaching.about.com/od/SchoolPolicy/a/Respect-In-Schools.htm.

Navodila za graditev osnovnih šol v Republiki Sloveniji [Instructions for the Construction of Primary Schools in the Republic of Slovenia] (2007). Ljubljana: Republika Slovenija, Ministrstvo za šolstvo in šport (Republic of Slovenia, Ministry for Education and Sports). Retrieved from http:// www.mss.gov.si/fileadmin/mss.gov.si/pageuploads/razpisi/investicije/prijava_investicij_navodila_

OS_8_6_07.pdf.

Nicholson, E. (2005). The School Building as Third Teacher. In M. Dudek (Ed.), Children's Space (pp. 44-65). New York: Routledge.

OECD Programme on Educational Building and Department for Education and Skills (2006). $21^{\text {st }}$ Century Learning Environment. OECD publishing. Retrieved from http://www.slideshare.net/ 
mem2009/20120924-21-st-21st-century-learning-environments-oecd.

PEB Exchange: The Journal of the OECD programme on Educational Building (2002). 2(46),1-28.

Retrieved from http://www.oecd.org/education/country-studies/34270691.pdf.

Playce (2012). Arhitekturni detektiv: Raziskuj, opazuj, začuti, prisluhni [Architectural Detectives:

Research, Observe, Feel, Listen]. Radovljica: Didakta.

Richards, J. C., \& Lockhart, C. (2007). Reflective Teaching in Second Language Classrooms.

Cambridge. New York, Melbourne: Cambridge University Press.

Rodari, G. (1996). Srečanje z domišljijo [The poetics of imagination]. Ljubljana: Mladinska knjiga.

Roncelli Vaupot, S. (2001). Z zakoni opredeljeni vloga, naloge, odgovornosti in imenovanje ravnateljev v državah Evropske unije in Slovenije - izhodišča za izobraževanje ravnateljev? In: Management v evropskem okolju: zbornik 1. strokovnega posveta Visoke šole za management $\mathrm{v}$ Kopru [Roles, tasks and responsibilities defined by laws and the appointment of school heads in the countries of the European Union and Slovenia - a platform for training school heads. In: Management in the European Context: Proceedings, 1. Scientific conference of the School of Management in Koper], Bernardin, SLO, 10-11 November 200o, pp. 215-228. Koper: Visoka šola za management. Retrieved from http://www.fm-kp.si/zalozba/ISBN/961-6268-64-3/215-228.pdf.

Schratz, M., Laiminger, A., MacKay, F.K.P., Křižková, E., Kirkham, G.A., Baráth, T. et. al. (2013). The Art and Science of Leading a School: Central 5: A Central European View on Competencies for School Leaders. Budapest: Tempus Public Foundation.

Sigurđardóttir, A. K., \& Hjartarson, T. (2011). School Buildings for the $21^{\text {st }}$ Century - Some Features of New School Buildings in Iceland. CEPS Journal, 1(2), 25-43.

Štemberger, T. (2013). Pomen ustvarjalnosti vzgojitelja v njegovi vzgojno-izobraževalni praksi [The role of preschool teacher's creativity in her/his educational practice]. Doktorska disertacija [PhD Thesis].

Koper: University of Primorska, Faculty of Education.

Taylor, A. (2009). Linking Architecture and Education: Sustainable Design for Learning Environments. Albuquerque: University of New Mexico Press.

Tomšič Čerkez, B., \& Zupančič, D. (2011). Physical Space and the Process of Education. CEPS Journal, 1(2), 5-9.

Vodopivec, A. (2014). Arhitekturna ustvarjalnost med sanjami in resničnostjo [Architectural

Creativity between Dreaming and Reality]. In I. Simoniti (Ed.), Ustvarjalnost [Creativity], (pp. 19-31). Ljubljana. Slovenska matica.

Woolfolk, A. (2002). Pedagoška psihologija [Educational Psychology]. Ljubljana: Educy.

Woolner, P. (2010). The Design of Learning Spaces: Future Schools. London: Continuum International Publishing Group.

Žajdela, I. (2013). Sobivanje na gori: Romanje treh Slovenij na Svete Višarje [Coexistence on the Mountain: The Pilgramage of three Slovenias on the Mountain Svete Višarje]. Družina, 82(32), 1. 


\section{Biographical note}

Professor Majda Cencič, PhD, works at the University of Primorska, Faculty of Education. She is engaged in different pedagogical topics; her interest have been in a wide range of areas - from the development of teacher education; educational research, assessment, evaluation; quality of physical learning environment; teacher as a reflective practitioner; and inclusive education - to the most recent issue of management of educational institutions and innovative learning environment. 